\title{
Isotopes and genes reveal freshwater origins of Chinook salmon Oncorhynchus tshawytscha aggregations in California's coastal ocean
}

\author{
Rachel C. Johnson ${ }^{1,2, *}$, John Carlos Garza ${ }^{1,3}$, R. Bruce MacFarlane ${ }^{1,4}$, \\ Churchill B. Grimes ${ }^{1,4}$, Corey C. Phillis ${ }^{5,8}$, Paul L. Koch ${ }^{6}$, Peter K. Weber ${ }^{7}$, Mark H. Carr ${ }^{2}$ \\ ${ }^{1}$ Fisheries Ecology Division, Southwest Fisheries Science Center, National Marine Fisheries Service, \\ National Oceanic and Atmospheric Administration, 110 Shaffer Road, Santa Cruz, CA 95060, USA \\ ${ }^{2}$ Department of Ecology and Evolutionary Biology, University of California, Santa Cruz, 110 Shaffer Road, Santa Cruz, \\ CA 95060, USA \\ ${ }^{3}$ Department of Ocean Sciences, University of California, Santa Cruz, 1156 High Street, Santa Cruz, CA 95060, USA \\ ${ }^{4}$ Institute of Marine Sciences, University of California, Santa Cruz, 110 Shaffer Road, Santa Cruz, CA 95060, USA \\ ${ }^{5}$ Department of Earth and Planetary Science, University of California, Berkeley, 307 McCone Hall, Berkeley, CA 94720, USA \\ ${ }^{6}$ Department of Earth and Planetary Science, University of California, Santa Cruz, 1156 High Street, Santa Cruz, CA 95060, USA \\ ${ }^{7}$ Glenn T. Seaborg Institute, Lawrence Livermore National Laboratory, 7000 East Avenue, Livermore, CA 94550, USA
}

${ }^{8}$ Present address: Metropolitan Water District of Southern California, 1121 L St. Suite 900, Sacramento, CA 95814, USA

\begin{abstract}
The ability of salmon to navigate from the ocean back to their river of origin to spawn acts to reinforce local adaptation and maintenance of unique and heritable traits among salmon populations. Here, the extent to which Chinook salmon Oncorhynchus tshawytscha from the same freshwater breeding groups associate together in the ocean at regional and smaller-scale aggregations prior to homeward migration is evaluated. Natural variation in salmon otolith daily growth bands, strontium isotopes $\left({ }^{87} \mathrm{Sr} /{ }^{86} \mathrm{Sr}\right)$, and microsatellite DNA were used as intrinsic tags to link the distributions of fish caught in the ocean with their freshwater origins. Adults were caught from vessels by hook and line in small aggregations (7-18 ind.) at the same geographic location (1-24 $\mathrm{km}$ of coastline) and time (4-36 h) from 3 ocean regions along central California, USA. Salmon caught together in aggregations were from the same genetic group, and to a lesser extent, of the same natal origin (individual rivers or hatcheries). However, at regional scales, adult salmon mixed. Central Valley winter-run Chinook salmon caught together in the ocean varied in the duration of freshwater rearing for up to 2-3 mo prior to seaward migration, suggesting associations within the group were not established in freshwater or maintained over the lifetime of the fish. Our findings are consistent with coarser information indicating stocks are distributed differently in time and space, but larger sample sizes are required to evaluate the consistency of patterns at smaller spatial scales. This study uncovers freshwater associations prior to homeward migration, a principle and undocumented prerequisite of the collective navigation hypothesis.
\end{abstract}

KEY WORDS: Winter-run Chinook salmon - Schooling - Otolith microchemistry - Strontium • Navigation

\section{INTRODUCTION}

Species that migrate long distances typically spend the majority of their lives away from their breeding sites. How conditions and events experienced by

${ }^{*}$ Corresponding author: rachel.johnson@noaa.gov migrating individuals affect survival and growth and how these, in turn, influence reproductive success remains one of the fundamental unresolved issues in the ecology of migratory species. A successful migratory life history depends on an organism's ability to

() P Koch, M Carr, C Phillis, P Weber 2016. Open Access under Creative Commons by Attribution Licence. Use, distribution and reproduction are unrestricted. Authors and original publication must be credited.

Publisher: Inter-Research · www.int-res.com 
find suitable habitat in all phases of the migratory cycle, and living in groups can provide fitness benefits to individuals (Krause \& Ruxton 2002). Schooling in fishes provides direct benefits gained through predator avoidance, increased foraging success and swimming efficiencies (reviewed in Pitcher \& Parrish 1993) and may greatly facilitate collective navigation in migratory species (Quinn 1984, Berdahl et al. 2014).

There is a rich and growing understanding of the complex spatial structure of salmon on their freshwater breeding grounds (Waples 1991, Hendry et al. 2000, Fullerton et al. 2011), but significantly less is known about their spatial structure and migratory behavior in their ocean foraging grounds, despite recent advancements (Weitkamp 2010, Tucker et al. 2012, Satterthwaite et al. 2013, Bellinger et al. 2015). Salmon have evolved complex mechanisms to navigate from the ocean and return to the river where they were spawned (Quinn \& Dittman 1990, Lohmann et al. 2008, Keefer \& Caudill 2013). The evolution of homing in salmon contributes to the highly variable life history patterns and genetic diversity characteristic of salmon species by facilitating local adaptation and a mosaic of genetically distinct groups across their freshwater breeding landscape. Indeed, in the USA, California's Central Valley (CV) supports 4 races of Chinook salmon Oncorhynchus tshawytscha with well-documented differences in their freshwater behaviors including timing of adult migration, spawning, and duration of juvenile freshwater rearing (Yoshiyama et al. 1998). CV Chinook salmon are named for the season adults leave the ocean and return to spawn (fall-, late fall-, winter-, and spring-runs) and are managed as 3 distinct evolutionarily significant units (ESUs, sensu Waples 1991, see Table 1). There is growing appreciation that salmon originating from the same genetic lineage may also exhibit stock-specific ocean distributions and behaviors (Pearcy 1992, Weitkamp 2010, Satterthwaite et al. 2014). Yet, little is known about the composition of salmon schools in the ocean and the extent to which salmon maintain lifetime associations with individuals from the same natal population.

Observing fish behavior in the open ocean is difficult, and accordingly, the social tendencies of salmon are not well understood. What is known about migratory patterns and large-scale ocean distributions of salmonids comes primarily from recoveries of artificial tags, use of stock-specific parasites, and differences in scale patterns (Neave 1964, French et al. 1976, Urawa et al. 1998). Recovery patterns of hatchery Chinook salmon coded wire tags (CWTs) reveal broad-scale spatial structure in the ocean and thus the potential for stock-specific responses to the environment or genetically controlled migratory behaviors in the ocean (Weitkamp 2010, Tucker et al. 2012, Satterthwaite et al. 2013). However, CWT studies rarely provide sufficient recoveries on small spatial scales to quantify segregation of individuals from the same genetic group or natal origin (operationally defined as fish originating from the same river or hatchery). An exception is work by McKinnell et al. (1997) that suggests steelhead trout O. mykiss released from the same hatchery were traveling in a coordinated manner $3 \mathrm{yr}$ after release.

Collective navigation in migrating animals may serve a critical role in assisting individuals in a group to geolocate suitable habitat during one or more life stages. The theory behind collective navigation in salmon is that an aggregation returning to their home river from the ocean can more accurately find the estuary and natal river by relying on the collective decisions of the group, thereby reducing the effects of navigational errors made by an individual (Berdahl et al. 2014). Berdahl et al. (2014) synthesized results from multiple studies showing that when more salmon were present, individual salmon were to less likely to stray from the correct navigation path, suggesting the possible role of collective navigation. There is strong evidence for a combination of geomagnetic and olfactory cues contributing to salmon homing to their natal rivers (Hasler \& Wisby 1951, Nordeng 1977, Putman et al. 2014). Berdahl et al. (2014) also found evidence that social interactions and collective behavior may function as additionally important cues. Yet, few empirical studies have examined the extent to which aggregations of salmon in the ocean are comprised of individuals from the same freshwater breeding population, a principle and undocumented prerequisite that would lend support to this hypothesis. Whether these associations are established early and maintained for a lifetime or are formed prior to homeward navigation remains unexplored and has significant consequences for salmon population dynamics.

In the past decade, there has been a rapid increase in the development of genetic and otolith microstructure and microchemistry techniques as intrinsic tags. These techniques can be used to understand migratory ecology and spatial structure in fishes at fine spatial scales, because all individuals potentially carry 'tags' that can identify their origin (Milton \& Chenery 2001, Miller et al. 2005, Sturrock et al. 2012). There is growing appreciation that these techniques, when applied together, can provide a greater understand- 
ing of place of origin and connectivity than either alone (Barnett-Johnson et al. 2010, Collins et al. 2013, Feyrer et al. 2015). Molecular techniques can detect restricted gene flow and the resultant genetic divergence among groups over evolutionary time scales (Waples 1991, O'Connell \& Wright 1997, Banks et al. 2000), whereas banding patterns and isotopes in otoliths reflect growth rate and environmental differences recorded by individuals on ecological time scales (Campana \& Thorrold 2001, Barnett-Johnson et al. 2007). Together, these tools can function synergistically to identify genetic lineage and environmental histories of individuals. This can then reveal the spatial scales at which genetic groups and local natal breeding populations mix in the open ocean and, moreover, the extent to which individuals within and among aggregations share similar freshwater rearing behavior and timing of outmigration.

California's Chinook salmon fishery and CV fall-run populations offer a model system to understand the composition of aggregations and lifetime associations of individuals from the same genetic groups and origins because analytical methods have been developed and validated at different spatial scales of freshwater structure-ESUs, hatchery from natural sources nested with the CV fall-run ESU, and individual natal rivers and hatcheries (Fig. 1). At the broadest scale (Fig. 1a), genetic stock identification (GSI) baseline reference databases distinguish the $3 \mathrm{CV}$ ESUs, as well as other ESUs, present in the fishery (Seeb et al.

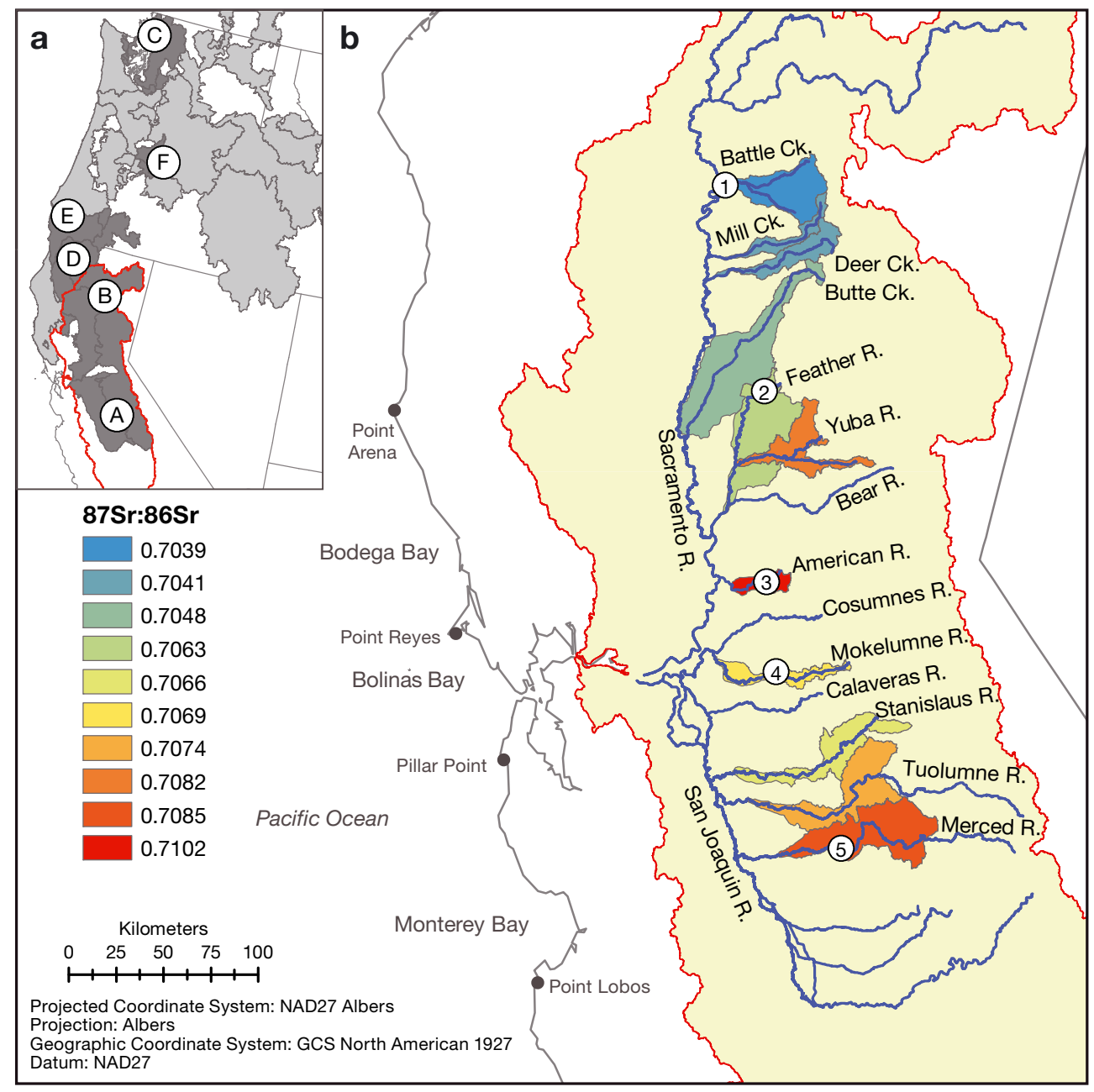

Fig. 1. Chinook salmon freshwater habitat, spatial structure hierarchy and ocean sampling regions. (a) Distribution of Chinook salmon evolutionarily significant units (ESUs, light and dark grey areas) and those stocks identified in ocean samples in this study (dark grey areas; letters); the Sacramento and San Joaquin river basins forming the California Central Valley (CV) are outlined in red. (b) Geographic regions of ocean sampling (between Point Arena and Point Lobos) and natal freshwater locations of natural (river names) and hatcheries (numbers) for CV fall-run salmon. Values of strontium isotopes. ${ }^{87} \mathrm{Sr} /{ }^{86} \mathrm{Sr}$, from otoliths of juvenile salmon collected in the CV rivers originally reported in Barnett-Johnson et al. (2008). In (a) the CV fall-run ESU occurs in the same habitat as Sacramento River winter-run ESU, but with additional habitat throughout the Sacramento and San Joaquin basins. Full ESU and hatchery names in Tables 1 \& 3 
2007, Clemento et al. 2014). Genetic assignments are typically reported as 'reporting groups', which are often the smallest group of populations that can be reliably distinguished with the genetic reference database. However, some GSI reporting groups are composed of multiple genetically similar populations (Seeb et al. 2007, Clemento et al. 2014), whereas others aggregate genetically distinct groups with similar management regimes, and reporting group boundaries do not always coincide with salmon runs or ESUs (discussed in Moran et al. 2006). For example, the CV fall-run genetic reporting group includes all CV fallrun populations as well as the genetically similar late fall-run and Feather River spring-run populations. At an intermediate scale, otolith banding patterns can discriminate hatchery and naturally produced fish within the CV fall-run (Barnett-Johnson et al. 2007, Fig. 1b). At the finest scale, strontium isotopes $\left({ }^{87} \mathrm{Sr} /{ }^{86} \mathrm{Sr}\right)$ in otoliths can identify individual rivers and hatcheries of natal origin (Barnett-Johnson et al. 2008, Fig. 1b).

Here, data from intrinsic genetic and otolith 'tags' were combined to test the extent to which Chinook salmon from the same freshwater breeding groups mix or associate in the ocean prior to homeward migration at 2 different spatial scales, i.e. regional or smaller-scale aggregations. Three specific questions are addressed: (1) Are individuals caught together in small-scale aggregations from the same genetic group or natal origin? (2) Are individuals from the same genetic group or natal origin found disproportionately in particular geographic regions off coastal California? (3) Do individuals from the CV winter-run stock caught together in the ocean show similar freshwater rearing behavior and outmigration timing?

\section{MATERIALS AND METHODS}

\section{Study system}

Historically, the dominant contributor to the California fishery from CV stocks were spring-run Chinook salmon that migrated in the spring and over-summered in deep cool pools in headwater streams prior to spawning in the fall (Yoshiyama et al. 1998). However, habitat modification, hatchery practices, harvest and water management have had serious impacts on CV salmon populations (Moyle 1994), particularly the springrun and the fall-run, with the fall-run heavily reliant on hatchery supplementation (Barnett-Johnson et al. 2007, 2012, Kormos et al. 2012). The fall-run is currently numerically dominant, while the spring- and winter-runs are now listed under the US Endangered Species Act as threatened and endangered, respectively (ESA, 70 FR 37160, Table 1). The $4 \mathrm{CV}$ salmon runs vary in their life history characteristics (Yoshiyama et al. 1998). Three of the 4 are also significantly different genetically, and GSI can be used to discriminate fish from the winter-run, spring-run (with the exception of the Feather River stock), and late fall-/fall-run ESUs (Moran et al. 2006, Seeb et al. 2007, Clemento et al. 2014). However, the $\mathrm{CV}$ fall-run reporting group is comprised of multiple local breeding populations of fish originating from several rivers and hatcheries that are genetically indistinguishable, yet play an important role in persistence of the ESU. The primary rivers and hatcheries (natal codes) that support the $\mathrm{CV}$ fall-run include: Battle (BAT), Deer (DEE), Mill (MIL), Butte (BUT) Creeks, Feather (FEA), Yuba (YUB), American (AME), Mokelumne (MOK), Stanislaus (STA), Tuolumne (TUO), and Merced (MER) Rivers, Coleman National Fish Hatchery $(\mathrm{CNH})$, Feather River Hatchery (FRH), Nimbus Fish Hatchery (NIH), Mokelumne River Fish Hatchery $(\mathrm{MOH})$, and Merced River Fish Hatchery (MEH) (Williamson \& May 2005; Fig. 1b).

Salmon fisheries along the West Coast of North America are mixed stock, comprised of multiple populations of salmon that co-mingle at different spatial scales and require different fishery exploitation rates to maintain long-term viability (PFMC 1997, Bellinger et al. 2015). Fishery managers aim to prevent over-harvesting of populations that can sustain little

Table 1. Status and location of 6 evolutionarily significant units (ESUs) and status under the US Endangered Species Act (ESA) of adults caught in the California ocean samples in this study with genetic reporting group codes in parentheses. These represent 6 of the 17 ESUs identified in Washington, Oregon, Idaho and California, USA. Salmon stocks in British Columbia excluded from table due to no stock evaluation under the US ESA, but are included in genetic analysis and reported as (BC coast). See Fig. 1 for map reference codes $(A)$ to $(F)$

\begin{tabular}{|c|c|}
\hline ESU & ESA listing status \\
\hline (A) Central Valley fall/late fall (CV fall-run) & Species of concern \\
\hline (B) Sacramento River winter (CV winter-run) & Endangered \\
\hline (C) Puget Sound (Puget Sound) & Threatened \\
\hline (D) Upper Klamath-Trinity (Klamath) & Not warranted \\
\hline $\begin{array}{l}\text { (E) Southern Oregon and northern California } \\
\text { coastal (OR-CA coastal) }\end{array}$ & Not warranted \\
\hline (F) Deschutes River summer/fall (Deschutes) & Not warranted \\
\hline
\end{tabular}


exploitation, so-called weak stocks, while allowing harvest on co-occuring abundant and productive stocks. The decline or collapse of a single widespread stock can result in the closure of an entire regional ocean fishery, as occurred in 2007 and 2008 with the collapse of the CV fall-run and closure of the California salmon fishery (Lindley et al. 2009). However, the weak stock in the California ocean salmon fishery varies over time, and the changes in abundance of fish from other stocks, such as those from the Klamath River or the presence of ESA-protected stocks such as the CV winter-run, can limit harvest opportunities of the usually dominant CV fall-run (PFMC 1997, O'Farrell et al. 2012). Thus, understanding the extent to which ESA-protected stocks are segregating regionally or in small aggregations provides relevant information necessary to reduce the vulnerability of weak stocks in harvest management.

\section{Field sampling}

Eighty-eight adult Chinook salmon (most commonly 3 yr old, O'Farrell et al. 2013) were caught from recreational charter and commercial fishery vessels by hook and line in small aggregations from 3 ocean regions along the central and north central coast of California (Fig. 1b): (1) Bodega Bay regionbetween Point Arena $\left(38^{\circ} 57.20^{\prime} \mathrm{N}, 123^{\circ} 44.30^{\prime} \mathrm{W}\right)$ and Point Reyes $\left(38^{\circ} 00.18^{\prime} \mathrm{N}, 123^{\circ} 01.30^{\prime} \mathrm{W}\right)$; (2) Bolinas Bay region - between Point Reyes and San Francisco Bay entrance $\left(37^{\circ} 48.40^{\prime} \mathrm{N}, 122^{\circ} 30.12^{\prime} \mathrm{W}\right)$; and (3) Monterey Bay region-between Pillar Point $\left(37^{\circ} 29.44^{\prime} \mathrm{N}, 122^{\circ} 29.59^{\prime} \mathrm{W}\right)$ and Point Lobos $\left(36^{\circ}\right.$ $31.26^{\prime} \mathrm{N}, 121^{\circ} 57.17^{\prime} \mathrm{W}$ ). Fish capture locations fell well within the defined regions and corresponded to vessel launching and landing locations. Finer spatial and temporal data are available for adult salmon collected on charter vessels than on commercial ves- sels, as in-field observers were present to collect metadata on charter vessels during shorter time intervals. Commercial vessels fished at times over $2 \mathrm{~d}$ in a region, and thus all samples could have been caught within a short or longer time interval. The longest possible time interval is reported as well as the broader geographic area (Table 2). Aggregations consisted of 7-18 individuals that were caught together during the same time period $(4-36 \mathrm{~h})$ in the same geographic location (1-24 km of coastline) on dates between May and October 2002 (Table 2). In total, 88 fish, were caught in 3 ocean fishery regions in 8 groups ( 3 in each of 2 regions and 2 in the other). Capture location, time, and ocean region were recorded for each individual.

A small piece of the pectoral fin was collected from each fish, dried on blotter paper and stored dry or frozen $\left(-80^{\circ} \mathrm{C}\right)$ for genetic analysis. Muscle tissue from the cheek was collected from some fish in the commercial fishery. Both sagittal otoliths were extracted, examined for aberrant calcium carbonate crystalline structure (vaterite), and archived dry for later isotope and microstructure analyses. In cases where only one otolith was aragonite, both analyses were conducted on this same otolith.

To identify the freshwater origin of fish collected in the ocean fishery, a 3-step process was used to combine data from genetic and otolith methods, which parallels the hierarchical scale of salmon freshwater structure (Fig. 1). First, genetic stock identification was used to assign fish to genetic reporting groups that generally correspond to salmon runs and ESUs (Moran et al. 2006). Adults from the CV fall-run reporting group were then identified as either having spent their early lives in rivers or in hatcheries using differences in otolith microstructure in the juvenile portion of the adult otolith (Barnett-Johnson et al. 2007). Lastly, the specific river or hatchery of origin of fish from the CV fall-run group was determined

Table 2. Ocean sampling regions and collection dates in 2002 of adult Chinook salmon off the central California coast, including the temporal resolution of sampling of aggregations. Code: aggregation code; time: duration of fishing operation

\begin{tabular}{|c|c|c|c|c|c|c|}
\hline Code & $\mathrm{N}$ & Region & Site & $\begin{array}{l}\text { Dates collected } \\
\text { (mo/d) }\end{array}$ & $\begin{array}{c}\text { Time } \\
\text { (h) }\end{array}$ & Fishery \\
\hline BB1 & 9 & Bodega Bay & $38^{\circ} 18.65^{\prime} \mathrm{N}, 123^{\circ} 06.42^{\prime} \mathrm{W}$ & $7 / 31$ & 12 & Commercial \\
\hline BB2 & 7 & Bodega Bay & $38^{\circ} 30.00^{\prime} \mathrm{N}, 123^{\circ} 20.87^{\prime} \mathrm{W}$ & $8 / 21-8 / 22$ & 36 & Commercial \\
\hline BB3 & 7 & Bodega Bay & $38^{\circ} 20.74^{\prime} \mathrm{N}, 123^{\circ} 08.62^{\prime} \mathrm{W}$ & $5 / 25$ & 4 & Recreational \\
\hline BO1 & 18 & Bolinas Bay & $37^{\circ} 47.17^{\prime} \mathrm{N}, 122^{\circ} 38.05^{\prime} \mathrm{W}$ & $9 / 11-9 / 12$ & 36 & Commercial \\
\hline $\mathrm{BO} 2$ & 11 & Bolinas Bay & $37^{\circ} 47.17^{\prime} \mathrm{N}, 122^{\circ} 38.05^{\prime} \mathrm{W}$ & $9 / 25-9 / 26$ & 36 & Commercial \\
\hline $\mathrm{BO} 3$ & 8 & Bolinas Bay & $37^{\circ} 47.17^{\prime} \mathrm{N}, 122^{\circ} 38.05^{\prime} \mathrm{W}$ & $10 / 5$ & 12 & Commercial \\
\hline MO1 & 18 & Monterey Bay & $36^{\circ} 39.10^{\prime} \mathrm{N}, 121^{\circ} 51.51^{\prime} \mathrm{W}$ & $8 / 8$ & 10 & Recreational \\
\hline MO2 & 10 & Monterey Bay & $36^{\circ} 41.46^{\prime} \mathrm{N}, 121^{\circ} 51.40^{\prime} \mathrm{W}$ & $7 / 31$ & 8 & Recreational \\
\hline
\end{tabular}


using differences in ${ }^{87} \mathrm{Sr} /{ }^{86} \mathrm{Sr}$, measured within portions of the adult otolith accreted while in natal habitats in combination with microstructure assignment (Barnett-Johnson et al. 2008).

\section{Genetic analysis}

DNA was extracted from $\sim 2 \mathrm{~mm}^{2}$ of fin $\left(\sim 5 \mathrm{~mm}^{3}\right.$ of cheek) tissue using DNeasy 96 kits on a BioRobot 3000 (Qiagen). Individuals were genotyped at 13 microsatellite loci using primers developed from multiple salmonid species (Seeb et al. 2007; Table S1 in the Supplement; www.int-res.com/articles/suppl/ m548p181_supp.pdf). These loci were selected based on a suite of criteria that made them compatible for many ecological and fisheries applications for Chinook salmon and tested for inter-laboratory measurement concordance (Seeb et al. 2007). Microsatellite loci were amplified using standard PCR conditions and were electrophoresed on a 3730 DNA Analyzer (Applied BioSystems). Alleles were called with GENEMAPPER (version 2.1) software. Two people determined the genotypes for all fish independently, and any discrepancies in scores were resolved or samples were reanalyzed.

Adults were identified to their genetic reporting group by comparison with a standardized reference baseline dataset of genotypes from these 13 microsatellite loci from 110 Chinook salmon populations ranging from Alaska to California (Seeb et al. 2007). Genetic stock identification was conducted on all fish with $>6$ loci genotyped using this baseline and the software gsi_sim (Anderson et al. 2008) and 2 measures of classification robustness and individual assignments (Anderson et al. 2008). There was strong agreement between the 'proportional' and 'equal' methods for individual assignments (Anderson et al. 2008). In fact, the strength of assignment (posterior probability) for all individuals in this study averaged $97 \%(\mathrm{SD}=8)$ using 'proportional' and $87 \%(\mathrm{SD}=23)$ for 'equal' estimates of stock composition.

\section{Central Valley fall-run natal assignment}

To identify the natal origins and segregation in the ocean of CV fall-run adults (assigned to genetic groups as described above), otoliths were selected for microstructure and ${ }^{87} \mathrm{Sr} /{ }^{86} \mathrm{Sr}$ measurements. Otoliths for both analyses were mounted sulcus side up on microscope slides with a thermoplastic resin (CrystalBond $509^{\circledR}$ ) and polished on both sides using
$\mathrm{Al}_{2} \mathrm{O}_{3}$ lapping paper until daily increments in the juvenile portion of the otolith were revealed per established techniques (Barnett-Johnson et al. 2005).

Otolith microstructure differences due to rearing environments have been shown to identify the hatchery or natural origin of Chinook salmon juveniles with 91\% accuracy (Barnett-Johnson et al. 2007). Specifically, otoliths from natural-origin fish are characterized by prominent exogenous feeding checks and narrower and more variable daily growth increments following yolk absorption than their hatcheryreared counterparts (Barnett-Johnson et al. 2007). The prominence of the exogenous feeding check, and the width and variation of 30 growth bands post exogenous feeding, were measured. A previously developed otolith microstructure baseline was used to assign fish to hatchery or natural origin (BarnettJohnson et al. 2007).

${ }^{87} \mathrm{Sr} /{ }^{86} \mathrm{Sr}$ ratios in otoliths vary among rivers across the geographic range of the CV fall-run due to differences in watershed geology and can be used to assign adult fish to individual hatchery or river of origin, which is unachievable using genetic stock identification (Williamson \& May 2005, Barnett-Johnson et al. 2008, Hobson et al. 2010; Fig. 1b). Juveniles were correctly classified to individual hatchery stocks (98\%) and natural river sources (94\%, when individuals from DEE and MIL, creeks closely associated geographically and geologically, were grouped together), providing a robust juvenile baseline to identify individual natal populations of origin in adults (Barnett-Johnson et al. 2008). Isotopic measurements were conducted in this study on adult otoliths that were grouped onto clean petrographic slides, randomized by catch location, and sampled using $60 \times 500 \times 80 \mu \mathrm{m}(\mathrm{W} \times \mathrm{L} \times \mathrm{D})$ laser tracks in the ventral region along the longest axis parallel to daily increments (5 $\mu \mathrm{m}$ per increment, $12 \mathrm{~d}$; Barnett-Johnson et al. 2005). Specifically, ${ }^{87} \mathrm{Sr} /{ }^{86} \mathrm{Sr}$ were measured in the region of the otolith accreted while in the natal river or hatchery but after yolk absorption and prior to outmigration ( 250 $\mu \mathrm{m}$ from primordia). Samples were analyzed on a New Wave UP213 nm Laser and ThermoFinnigan Neptune MCICPMS, with specific instrument, laser, and interference corrections described in Ramos et al. (2004). Early life history migratory behaviors were characterized for individuals from the CV winter-run (determined by GSI, as described above) by measuring ${ }^{87} \mathrm{Sr} /{ }^{86} \mathrm{Sr}$ in abutting spots (60 $\mu \mathrm{m}$ diameter) along a transect from the juvenile primordia core of the otolith, past ocean entry per established techniques (Phillis et al. 2011). 
Adult fish were assigned to populations of origin using juvenile baselines previously reported and described as the 'separate model', which uses both the microstructure and ${ }^{87} \mathrm{Sr} /{ }^{86} \mathrm{Sr}$ analyses results in a single discriminant function (Barnett-Johnson et al. 2008). Nine individuals were considered compromised for microstructure analyses due to the occurrence of 2 vateritic otoliths and were assigned to natal populations using strontium isotope ratios and the 'full model', which does not necessitate the differentiation of hatchery or natural origins prior to classification (Barnett-Johnson et al. 2008).

\section{Small-scale associations in the ocean}

The extent to which individuals from the same genetic group were found together within aggregations at frequencies higher than expected by chance alone (i.e. proportional to the total from that genetic group) was determined by comparing observed distributions to a null distribution of expected frequencies generated using a randomization test of the total samples collected in Resampling Stats software version 3.2 (Resampling Stats Inc.). Unlike a chi-square test, this approach is robust for datasets with small numbers of observations per statistical group. For each genetic group, a simulation (1000 iterations) was conducted using the total number of fish from a given genetic group to determine the frequency with which fish would be expected to occur together across the 8 potential aggregations weighted by their sample sizes. Only groups represented by multiple observations ( $>1$ fish, CV fall-run, CV winter-run, southern Oregon and northern California coastal [OR-CA coastal], and Upper Klamath-Trinity [Klamath]) were evaluated. Three individuals representing single observations from different genetic reporting groups (Deschutes, British Columbia, and Puget Sound) were excluded from the analysis. Comparison of the observed occurrence of fish from the same genetic group with that predicted by the simulations indicates the likelihood of non-random aggregation. If the likelihood of the observed number of fish from a particular genetic group in an aggregation was less than 0.05 , then non-random aggregation of fish by genetic group was inferred.

To determine the extent to which individuals from the same natal origin were segregating at small spatial scales, otolith microstructure and ${ }^{87} \mathrm{Sr} /{ }^{86} \mathrm{Sr}$ ratios were used to assign fish to natal sources, and the same randomization approach as described above was used. The likelihood of the observed pattern of association of fish from each natal river or hatchery across the 8 aggregations was determined by comparison with the simulated null distribution. Only natal origins represented by multiple observations (>1 fish) within the CV fall-run group were evaluated for spatial patterns. These included fish from the $\mathrm{MOH}, \mathrm{NIH}, \mathrm{CNH}, \mathrm{FRH}$, and $\mathrm{MEH}$, as well as the TUO AME, and STA (natal codes and geographic locations referenced in Table 3 and Fig. 1).

\section{Regional associations in the ocean}

To determine whether fish from the same genetic group were geographically segregated by ocean fishery regions (Bodega Bay, Bolinas Bay and Monterey Bay regions, see above), the composition of aggregations was evaluated by ANOSIM and cluster analysis (similarity profiles [SIMPROF] test) using PRIMER (version 6.1.5) software (Plymouth Routines in Multivariate Ecological Research; Clarke \& Gorley 2006). ANOSIM is a multivariate randomization procedure particularly robust to frequency data containing real zeros and broadly analogous to ANOVA (Clarke 1993). Consequently, ANOSIM has been used widely for testing hypotheses about spatial differences in species assemblages (Chapman \& Underwood 1999). The analysis involves the production of a similarity matrix and generates an output statistic, $R$, which indicates the magnitude of difference in pairwise comparisons of regions and is scaled between -1 and +1 , where a value of zero represents the null

Table 3. Potential natal rivers and hatcheries contributing to the dominant $\mathrm{CV}$ fall-run genetic reporting group in the California ocean fishery. Numbers and codes for the hatcheries are referenced in Fig. 1

\begin{tabular}{|lc|}
\hline Natal origins & Natal code \\
\hline (1) Coleman National Fish Hatchery & CNH \\
(2) Feather River Hatchery & FRH \\
(3) Nimbus Fish Hatchery & NIH \\
(4) Mokelumne River Fish Hatchery & MOH \\
(5) Merced River Fish Hatchery & MEH \\
(6) Battle Creek & BAT \\
(7) Deer and Mill Creeks & DEE/MIL \\
(8) Butte Creek & BUT \\
(9) Feather River & FEA \\
(10) Yuba River & YUB \\
(11) American River & AME \\
(12) Mokelumne River & MOK \\
(13) Stanislaus River & STA \\
(14) Tuolumne River & TUO \\
(15) Merced River & MER \\
\hline
\end{tabular}


hypothesis (no difference among regions): $R<0$, regional compositions are more similar than expected by chance alone; $R=0$, they are indistinguishable; $0<R<0.25$, they are nearly indistinguishable; $0.25<R<0.5$, they overlap substantially; $0.5<R<$ 0.75 , they overlap but are clearly different; $0.75<R<$ 1.0 , they are well separated; and $R=1$, they are completely separate. Aggregations were grouped according to the 3 regions from which they were collected and treated as replicates to test for the effect of regional segregation of salmon groups using ANOSIM.

Patterns of similarity in composition of aggregations among regions were further evaluated with cluster analysis (SIMPROF test) PRIMER (version 6.1.5) software (Clarke \& Gorley 2006). The SIMPROF test used the Bray-Curtis similarity matrix to implement a hierarchical agglomerative clustering routine using the group average to determine the similarity of the composition of aggregations. Because 'region' is not an explicit factor in the analysis, the results could potentially identify groupings other than those from ANOSIM. The SIMPROF test was used to determine actual structure in the subset of data corresponding to each branch by calculating the distance between clusters of the dendrogram using 1000 permutations. A region effect using the cluster analysis was inferred when the SIMPROF test failed to detect a difference among aggregations at a 0.05 significance level. This significance level was relaxed to 0.25 to test for potential effects of low replication or power to detect regional structure.

To determine whether fish from the same natal populations were found geographically segregated among the Bodega Bay, Bolinas Bay and Monterey Bay regions, the same statistical approach as described above for genetic group regional segregation was used. In this case, only CV fall-run fish were analyzed, and the composition of aggregations with respect to natal populations was evaluated across the same 8 aggregations and 3 regions using ANOSIM and SIMPROF.

\section{Diversity in outmigration behavior for CV winter-run aggregations}

To determine whether fish from the same genetic group and natal origin found together in the ocean had similar freshwater migration history, and thus may have associated together over a lifetime, individual freshwater habitat use and movement patterns from the $\mathrm{CV}$ winter-run fish caught in the same aggregation were reconstructed. ${ }^{87} \mathrm{Sr} /{ }^{86} \mathrm{Sr}$ were measured in spots along a transect across the otolith from the juvenile primordia to ocean entry per established techniques (Phillis et al. 2011). Seven (of 9) CV winter-run fish that were caught in the same aggregation had otoliths intact for further examination.

\section{RESULTS}

The 88 fish sampled in the ocean along the central California coast in 2002 (Fig. 2, Table 2) assigned to 6 of the 17 genetic reporting groups described from Washington, Oregon, Idaho and California (Seeb et al. 2007). Within the CV fall-run group, adults from 10 rivers or hatcheries were detected (Table S2 in the Supplement at www.int-res.com/articles/suppl/m548 p181_supp.pdf). Fish collected off the Central California coast came from locations as distant as British Columbia and have a variety of listing status under the ESA, thus highlighting the importance of understanding the spatial scales of mixing of ESA-protected stocks in this mixed-stock fishery (Table 1).

\section{Small-scale associations in the ocean}

Aggregations were largely comprised of salmon from the same genetic group. All 4 genetic groups that met the minimum criteria for spatial analysis $(\mathrm{CV}$ fall-run, CV winter-run, Klamath, and OR-CA coastal) showed significant associations by aggregations. For example, all 9 fish from the CV winter-run (Table S3 in the Supplement) were in a single aggregation (MO1) in Monterey Bay. The probability that they would all be caught in one aggregation rather than distributed across the 8 aggregations assuming random distribution is $\mathrm{p}<0.001$ (Fig. 2). This same pattern was found for the 6 Klamath fish and OR-CA coastal fish where fish from those freshwater breeding groups were disproportionately found in single aggregations ( $p<0.015$; Fig. 2). Fish from the CV fall-run were in all aggregations, yet one aggregation (BO1) had significantly fewer CV fall-run relative to the expected random distribution of observations among the 8 aggregations $(p=0.007)$.

Similarly, the results are consistent with populationspecific associations of adults from the same natal origin. Using otolith microstructure and ${ }^{87} \mathrm{Sr} /{ }^{86} \mathrm{Sr}$ ratios in otoliths (Fig. 1b), a disproportionate number of individuals originating from 2 particular hatcheries were in the same aggregation. Specifically, fish from NIH and $\mathrm{MOH}$ were in single aggregations at significantly 
Fig. 2. Genetic composition of aggregations. Proportion of genetic reporting groups within aggregations. ${ }^{*}$ Likelihood values $(<0.01)$ indicating significant spatial segregation by genetic groups. Codes for genetic reporting groups, aggregations, and regions in Tables $1 \& 2$

greater than expected frequencies relative to a random distribution of observations among aggregations $(\mathrm{p}=0.017$ and $\mathrm{p}=0.046$, Fig. 3). However, fish from other natal origins $(\mathrm{CNH}, \mathrm{FRH}$, TUO, MEH, AME, and STA) did not show similar associations.

\section{Regional associations in the ocean}

Adult Chinook salmon from different genetic groups mixed among the 3 regions off the California coast. Aggregations within the 3 regions were not comprised of fish from the same genetic group (Fig. 4a). When the effect of region was explicitly tested, there was no evidence of segregation of fish by genetic groups at this regional scale (ANOSIM, global $\mathrm{R}=$ 0.129). The cluster analysis did not detect additional structure in the data due to geographic locations. For example, the composition of aggregation BO2, sampled in Bolinas Bay, was more similar in genetic composition to $\mathrm{MO} 2$, an aggregation in Monterey Bay, than to others in the Bolinas Bay region. This was the case for aggregations in all 3 regions with no significant clusters in the dendrogram (Fig. 4a). Relaxing the significance value to 0.25 did not change this, indicating sufficiently large sample sizes to detect regional segregation.

Similarly, adults from the same natal origin as identified by otolith microstructure and ${ }^{87} \mathrm{Sr} /{ }^{86} \mathrm{Sr}$ ratios were not found to be preferentially distributed in any of the Bodega Bay, Bolinas Bay and Monterey Bay regions. Aggregations within regions were not found with ANOSIM and cluster analysis to be similar in their natal origin composition (Fig. 4b). The global R value in the ANOSIM analysis was 0 , consistent with the null hypothesis that there was no regional effect on natal population distributions. The cluster analysis dendrogram revealed no additional spatial structure, and the results did not change when the significance value was relaxed to 0.25 .
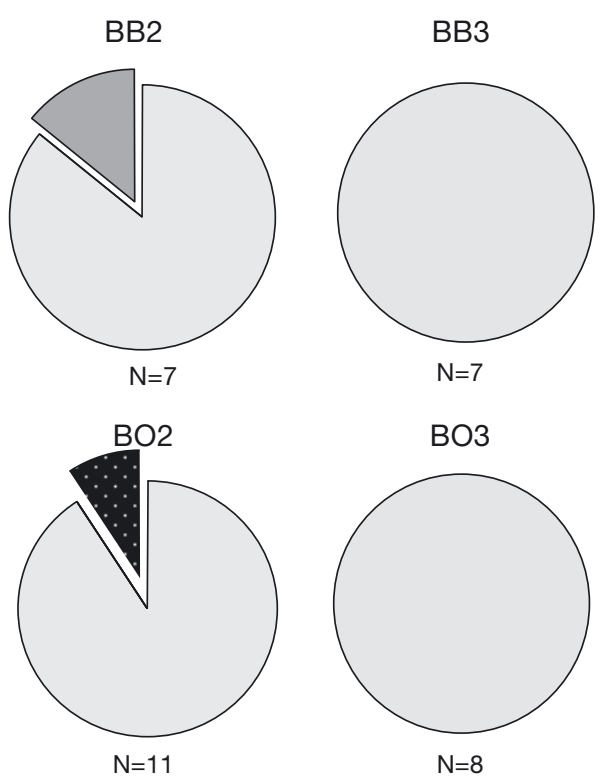

$\mathrm{MO1}$
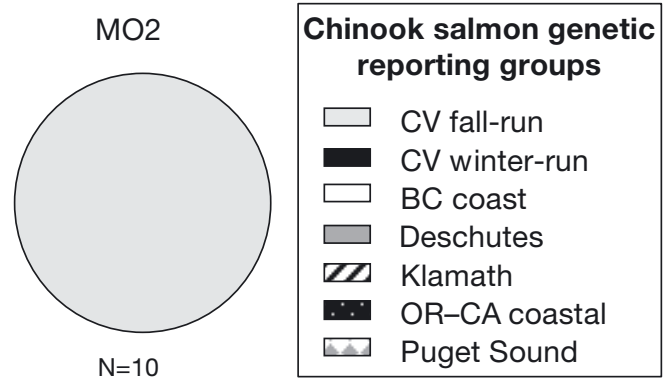

\section{Diversity in outmigration behavior}

Similarity in juvenile freshwater habitat use and migration behavior, as revealed by synchrony in the pattern of ${ }^{87} \mathrm{Sr} /{ }^{86} \mathrm{Sr}$ ratios across the early life history portion of adult otoliths from salmon caught in the same aggregation, would suggest coordinated associations over their lifetimes. Here, individual winterrun adults caught together showed a broad range of freshwater rearing duration in the Upper Sacramento River $\left({ }^{87} \mathrm{Sr} /{ }^{86} \mathrm{Sr}=0.70497\right.$; Ingram \& Weber 1999) prior to seaward migration, suggesting a diversity of early juvenile rearing and migratory behaviors (Fig. 5). Specifically, one individual left the upper Sacramento River at a size represented by a $\sim 350 \mu \mathrm{m}$ distance in the otolith, while another remained in the upper Sacramento River and migrated at an otolith distance of approximately $600 \mu \mathrm{m}$. This 2-fold observed variation in outmigration distance on the otolith corresponds to a difference of 2-3 mo, depending on growth rates (3-4 $\mu \mathrm{m}$ otolith deposition per day; Barnett-Johnson et al. 2007). These data suggest that the individuals caught in the ocean 


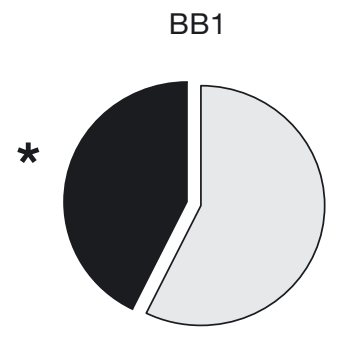

$\mathrm{N}=7$

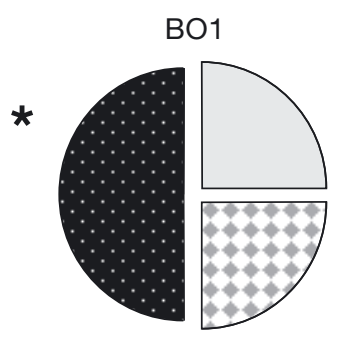

$\mathrm{N}=4$

MO1

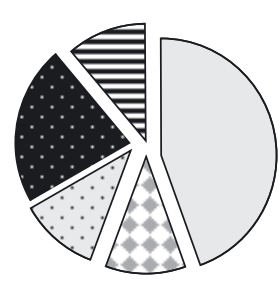

$\mathrm{N}=9$

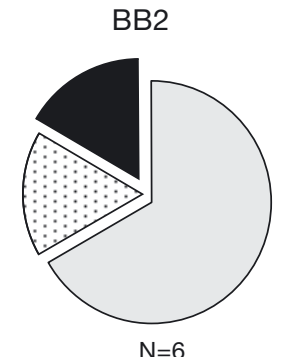

$\mathrm{BO} 2$

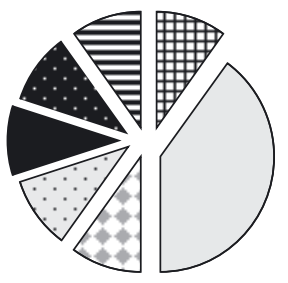

$\mathrm{N}=8$

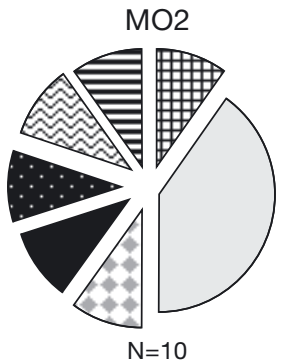

BB3

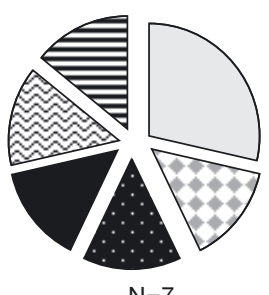

$\mathrm{BO} 3$
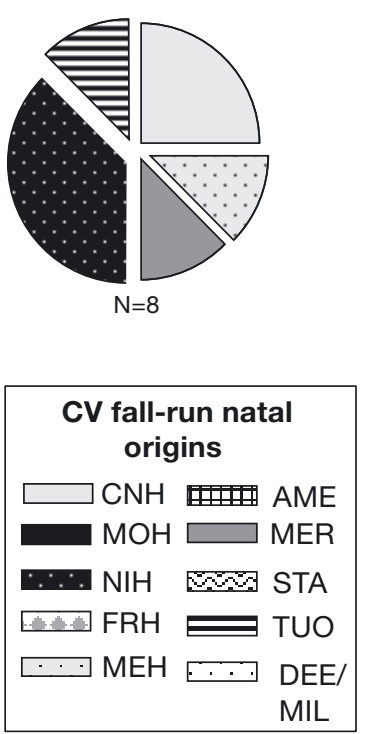

Fig. 3. Natal origins of $\mathrm{CV}$ fall-run Chinook salmon within aggregations. ${ }^{*}$ Likelihood values $(<0.05)$ indicate significant spatial segregation by natal sources. Aggregation codes and natal codes referenced in Tables 2 \& 3

together did not experience coordinated rearing and outmigration behavior during early freshwater residence, with one pair of fish (MK20019 and MK20024) a potential exception.

\section{DISCUSSION}

Identifying the spatial scales of mixing for migratory fish species is critical to understanding their ecology, and improving sustainable management of weak-stock fisheries. Further, aggregating with related individuals may provide navigational benefits and have adaptive significance. The combination of intrinsic genetic (microsatellite DNA) and environmental tags (otolith microstructure and ${ }^{87} \mathrm{Sr} /$ ${ }^{86} \mathrm{Sr}$ ratios), as used in this study, de-
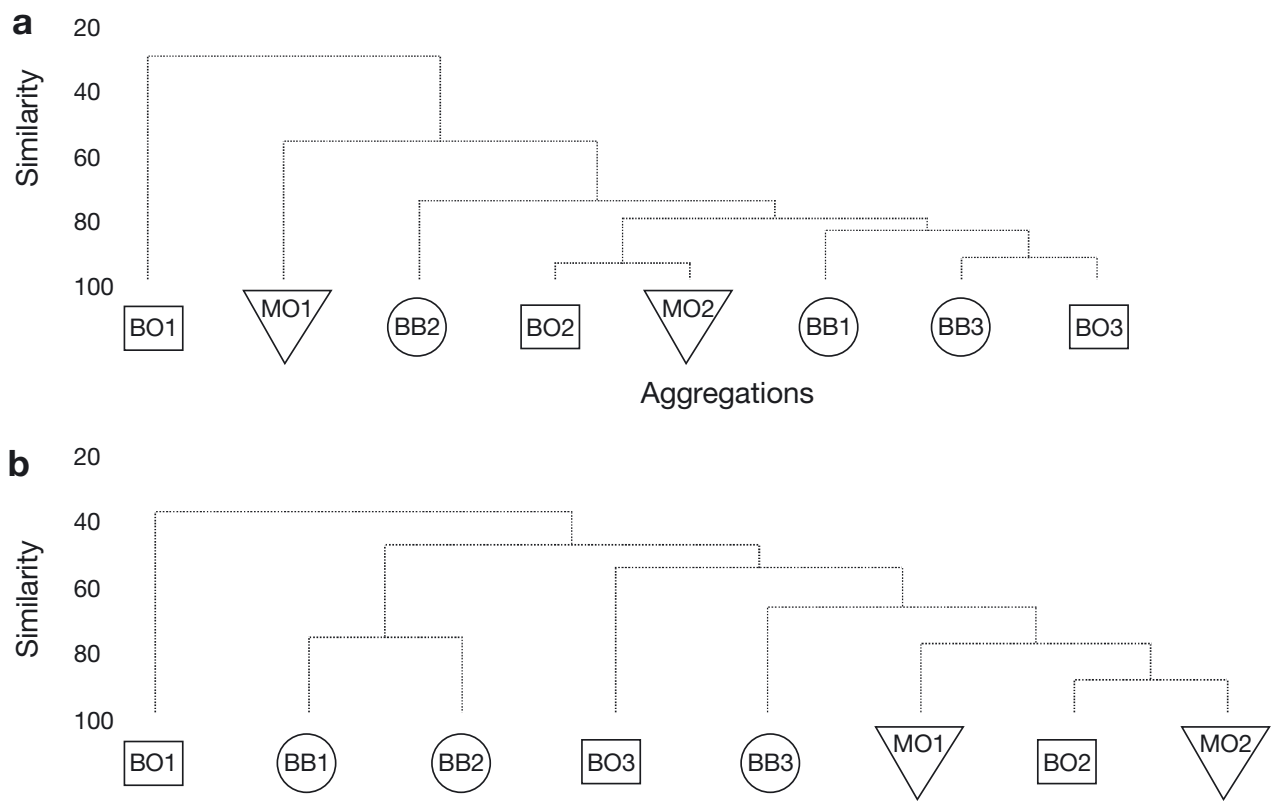

Aggregations

Fig. 4. Genetic and natal origin associations of CV fall-run Chinook salmon by ocean regions: Bodega Bay (circles), Bolinas Bay (rectangles), and Monterey Bay (triangles). Similarity of the 8 sampled aggregations based on their (a) genetic composition and (b) natal origins. Cluster analysis (group average) was used to generate the dendrogram. SIMPROF analysis confirms no segregation of genetic groups or natal origins across regions. Aggregation codes and regions referenced in Table 2 


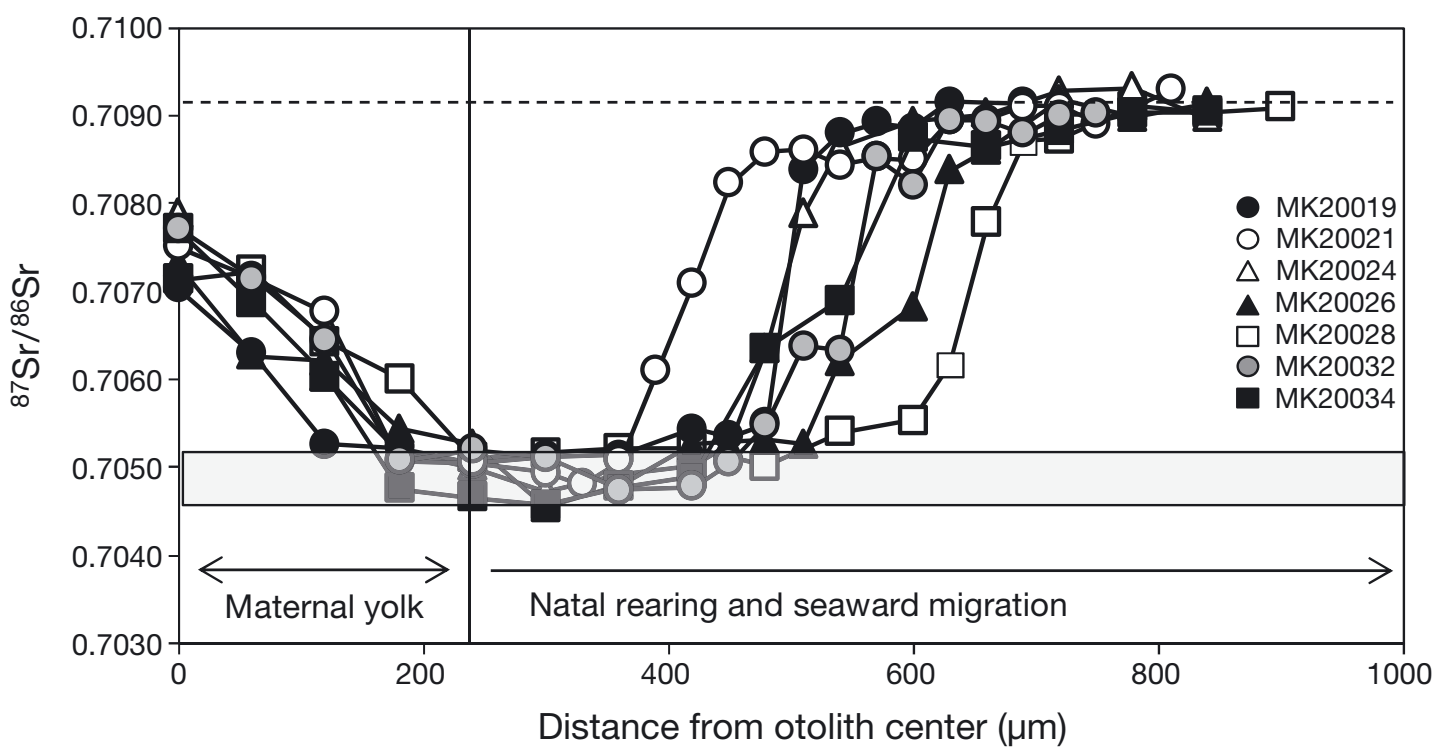

Fig. 5. Early freshwater rearing and migration of adult California Central Valley (CV) winter-run Chinook salmon. ${ }^{87} \mathrm{Sr} /{ }^{86} \mathrm{Sr}$ ratios from 7 adult Chinook salmon caught together in the coastal ocean and assigned genetically to the CV winter-run. ${ }^{87} \mathrm{Sr} /{ }^{86} \mathrm{Sr}$ is expressed as a function of distance from the center of the otolith and records distinct environments as the otolith accretes. Prior to complete yolk absorption (first $\sim 250 \mu \mathrm{m}$, vertical line), ${ }^{87} \mathrm{Sr} /{ }^{86} \mathrm{Sr}$ represents a mixture of maternal marine yolk values $\left({ }^{87} \mathrm{Sr} /{ }^{86} \mathrm{Sr}=0.70918\right.$ dashed line) and upper Sacramento River water (grey box, mean ${ }^{87} \mathrm{Sr} /{ }^{86} \mathrm{Sr}=0.70497$, Ingram \& Weber 1999). Once yolk absorption is complete, exogenous feeding begins and otolith ${ }^{87} \mathrm{Sr} /{ }^{86} \mathrm{Sr}$ reflects water and prey values encountered during natal rearing and seaward migration. Average SE on each spot measurement (60 $\mu \mathrm{m}$ diameter) is \pm 0.00011

tected patterns in the ocean distribution of Chinook salmon that would not have been elucidated with a single approach. Combined, the approaches resolved the spatial scales of ocean mixing of genetically similar groups, natural and hatchery sources, as well as individual natal origins, all of which have implications for understanding the basic ecology and management of salmonids.

Little is known about the specific spatial scales of mixing of salmon populations or the role of spatial structure on their ocean ecology. We know from CWT recoveries of hatchery fish, and to a lesser extent wild salmon, that certain stocks tend to distribute differently in time and space in the ocean (Nicholas \& Hankin 1989, Weitkamp 2010). Population-specific differences in marine distribution patterns have been observed in coho Oncorhynchus kisutch and Chinook salmon on broader geographic scales through analysis of CWT recoveries (Myers et al. 1998, Norris et al. 2000, Weitkamp 2010, Satterthwaite et al. 2013). This is further supported by substantial regional growth differences observed in coho salmon returning to Oregon and Washington, suggesting these fish experienced different conditions, and inhabited different parts of the ocean, over a significant amount of time (Weitkamp \& Neely 2002, Wells et al. 2008). Regional segregation could be important in understanding variation in marine survival in salmonid populations (Ryding \& Skalski 1999, Wells et al. 2006).

Experiments demonstrate that there is a genetic component to the tendency for stocks to have similar marine migrations and non-random distribution at regional scales in the ocean, but they also show that salmon from a given population are found over a broad distribution of the available habitat (Quinn 2011, Bellinger et al. 2015). Therefore, it is clear that all salmon from a single population do not exhibit full fidelity to a single population-specific aggregation in the ocean, likely due to a broad temporal window of smolt outmigration timing in many stocks. Thus, salmon share population-specific distribution features at some spatial scales, yet at other scales they do not. Our study found that at the regional scales defined in this study, Chinook salmon did not segregate by genetic group or natal origin. Rather, all 4 genetic groups (CV winter-run, Klamath, CV fallrun, and OR-CA coastal) showed statistically significant associations at smaller-scale aggregations. In fact, all 9 fish from the CV winter-run were aggregated within the Monterey Bay region while another aggregation in the region was fully comprised of salmon from the CV fall-run. This small-scale association of $\mathrm{CV}$ winter-run in this region is compatible 
with recent work that suggests $\mathrm{CV}$ winter-run may concentrate in the Monterey Bay region, albeit this study detects an association at even smaller-scales (Winans et al. 2001, Satterthwaite et al. 2013).

This study provides evidence for genetic and natal origin associations beyond juvenile stages in Chinook salmon. While most aggregations are not perfectly assorted into wholly uniform groups, there were significant associations of individuals from the same genetic and natal populations, which may have been formed prior to homeward migration. Reconstructed early migratory behaviors from the same CV winter-run, genetic group, and origin caught together in the ocean provide insight into when the observed associations were likely established. Although the sample sizes are small, analyses demonstrated a broad diversity in the duration of freshwater rearing and migratory behavior, suggesting stock-specific sorting likely occurs in the ocean following freshwater outmigration and not during freshwater residency. However, further studies are necessary to identify when these associations are formed in the ocean.

The ocean environment is vast, complex and unpredictable, providing ample opportunity for juvenile salmon originating from the same sources to disperse from one another. Associating with related individuals may arise as a result of one or a combination of habitat selection, passive segregation, or active aggregation. For example, the observed behavior may arise as a byproduct of individuals having genetic predispositions to migrate to similar places at similar times or follow the same environmental foraging and oceanographic cues (Bentzen et al. 2001, Olsén et al. 2004, Fraser et al. 2005). While this may be responsible for large-scale patterns in ocean distributions, it is unlikely to be the dominant mechanism shaping the pattern of genetic group and natal population associations at the smaller spatial scales observed here. The observation of several small aggregations comprised of non-random associations of fish co-occuring in the same regions is consistent with the mechanism of active association of familiar individuals or individuals with similar run timing.

Whether the initial cue for these associations is genetic, environmental or phenotypic, and whether the same cue is used to reinforce these associations in the adult life history, remains unknown. Some evidence of stable associations exists in diverse fish species (yellow perch Perca flavescens, Helfman 1984; skipjack tuna Katsuwonus pelamis, Hilborn 1991; European minnow Phoxinus phoxinus, Naish et al. 1993; yellowfin tuna Thunnus albacares, Klimley \& Holloway 1999; Pacific herring Clupea pallasi, Hay
\& McKinnell 2002; 3-spined stickleback Gasterosteus aculeatu, Ward et al. 2002; gupp Poecilia reticulata, Russell et al. 2004). In salmonids, Pearcy (1992) reported 19 tagged coho salmon from the Columbia River in a seine haul a month after release. The same population-specific patterns were found for steelhead from the same hatchery that were found associating together $3 \mathrm{yr}$ after hatchery release (McKinnell et al. 1997).

Several potential benefits to fishes of aggregating with related individuals have been theorized, including the Migration Enhancement Hypothesis (reviewed in Pitcher \& Parrish 1993), the Collective Navigation Hypothesis (Berdahl et al. 2014), and the Entrainment Hypothesis (ICES 2007). Yet, few empirical studies provide definitive results to support or refute these hypotheses. Hart et al. (2014) showed juvenile grayling Thymallus thymallus were more likely to enter and forage in new upstream habitats when paired with familiar versus unfamiliar social partners. Additionally, fitness benefits have been shown experimentally in juvenile brown trout that aggregate with related individuals. These individuals had increased response rates to predator attacks and improved foraging success (Griffiths et al. 2004). These adaptive responses have been attributed to an individual's reduced attention to competition with familiar individuals and thus increased ability to avoid predators and capture prey. In the present study, it is demonstrated that salmon caught together in the ocean are generally comprised of adults from the same genetic group and, in some cases, origin, a prerequisite for the occurrence of collective navigation. The adaptive significance of traits related to natal philopatry and migration timing are well supported (Ricker 1972, Quinn \& Dittman 1990, Taylor 1991). Indeed, the 4 runs of CV Chinook salmon differ in their peak season of maturation and homeward migration, as well as in their patterns of spawning habitat utilization. Associating with individuals from the same temporal run prior to homeward migration could serve to synchronize spawning and improve the ability of individuals to locate natal breeding areas (Olsén 1989).

Small-scale segregation by salmon from the same genetic group could influence management of mixedstock fisheries, depending on the properties of the aggregations and the timing of associations. If individuals from endangered stocks are rare, but distributed randomly among abundant stocks, then encounter rates would be proportional to their low frequency. However, if protected stocks are segregated on small spatial scales, they could be vulnerable to local overexploitation, since fishing effort is patchy and once a 
school is encountered, it is often heavily fished. They could be particularly impacted if they are concentrated in relatively few aggregations which are encountered at a disproportionately high rate, by chance or due to differences in their distribution relative to the fishery. To the extent that membership in such aggregations is stable, understanding the number, size and distributions of aggregations, could help predict the influence of stock-specific fishing mortality. The rich literature on models of predator encounter with fish prey schools may play a more pivotal role in improving fisheries management and conservation than previously recognized (Czaran 1998).

Most habitat restoration efforts for salmonids are focused in freshwater habitats at the scale of individual rivers (e.g. origin). Therefore, identifying the relative contributions of populations from these rivers to the various salmon runs is important for recovery efforts. Otolith microstructure and ${ }^{87} \mathrm{Sr} /{ }^{86} \mathrm{Sr}$ data allowed for this finer-scale identification of natal origin in CV fall-run salmon, which cannot be discriminated with GSI, due to hatchery practices (Williamson \& May 2005). Spatial structure was found in $2(\mathrm{MOH}$ and NIH) out of 8 natal populations. The small number of natural-origin fish in the ocean sample $(<25 \%)$ prohibited the determination of whether they occur in population-specific aggregations. More extensive sampling would provide additional insight into the prevalence of this behavior for natural-origin salmon populations.

Molecular genetic markers, combined with natural otolith tags, provide complementary information for fisheries ecology. In this study, genetic analysis provided insight into the segregation of individuals by genetic groups, and otolith ${ }^{87} \mathrm{Sr} /{ }^{86} \mathrm{Sr}$ and microstructure analyses identified natal origins, discriminated hatchery from natural-origin fish, and reconstructed rearing behaviors. The genetic assignments provided an independent confirmation of the robustness of ${ }^{87} \mathrm{Sr} /{ }^{86} \mathrm{Sr}$ to identify the natal origins and migratory behaviors of $\mathrm{CV}$ winter-run. For example, CV winterrun spawn and rear as a single population in the upper Sacramento River, thus they should all have similar ${ }^{87} \mathrm{Sr} /{ }^{86} \mathrm{Sr}$ values that match the water chemistry. Indeed, the ${ }^{87} \mathrm{Sr} /{ }^{86} \mathrm{Sr}$ values during the juvenile rearing period for all genetically identified $\mathrm{CV}$ winterrun $(0.704975, \mathrm{SD}=0.00010, \mathrm{n}=9)$ were within the margin of error of previously reported water chemistry data for the Sacramento River upstream of Battle Creek, CA (Ingram \& Weber 1999). All non-fall-run ESU fish had ${ }^{87} \mathrm{Sr} /{ }^{86} \mathrm{Sr}$ values within the range observed for CV fall-run natal rivers and hatcheries, with the exception of the individual identified as a
British Columbia-origin fish, whose ${ }^{87} \mathrm{Sr} /{ }^{86} \mathrm{Sr}$ ratio was lower than that of natal sources for the CV fallrun stock (Table S3). Thus, for mixed-stock ocean fisheries, the combination of these approaches maximizes information regarding the spatial distribution in the coastal ocean of fish from these populations.

If the ocean spatial associations found in this study are also found in other migratory species that exhibit philopatry to feeding or breeding grounds, then maintaining an association with individuals from the same genetic or natal origin during migration may represent an underappreciated process that aids in the successful return of individuals to habitats that confer fitness benefits (Feyrer et al. 2015). The ability to recognize and associate preferentially with individuals from the same genetic or natal group is common across animal taxa (mammals, Porter et al. 2001; birds, Senar et al. 1990; reptiles, Bull et al. 2000; insects, Clark et al. 1995) and is particularly prevalent in fishes (Griffiths 2003). Other fishes that are candidates for exhibiting the presence of long-term associations during migrations on the basis of common genetic or natal group origins include other salmonid species, sturgeon, Sacramento splittail, weakfish, American shad, and striped bass, all of which show high fidelity to natal locations. Further application of combined analysis of genetic and isotopic tags to understand the composition of aggregations may provide further evidence for the migration enhancement hypothesis and support the importance of this pattern in maintaining locally adapted populations in migratory species.

\section{CONCLUSION}

Identifying the genetic group, natal origins and early life history behavior of adult Chinook salmon in ocean aggregations is unprecedented. By combining the complementary information provided by molecular genetic stock identification and otolith microstructure and isotopic techniques, spatial patterns in the ocean ecology of Chinook salmon that are important to both basic and applied research were revealed. These findings suggest that there is some degree of association in the composition of aggregations at the level of genetic groups and natal origins. One limitation of this study is that a deeper understanding is needed to determine the extent to which salmon collected on fishing excursions defined as aggregations were indeed close enough to each other to gain group-association benefits. However, the potential limitation of integrating over multiple social aggrega- 
tions in the commercial samples does not compromise the observed strong associations between freshwater breeding groups at small scales. More detailed studies with larger sample sizes determining how often aggregations occur, at what rate individuals are exchanged, the strength of fidelity, the number of aggregations present in a given area, and the duration of time they remain in an area would greatly increase our understanding of the organization and behavior of these groups of associated fish. Further studies combining molecular genetic identification, otolith or other environmentally influenced intrinsic tags, and/ or electronic tags, where associations could be followed over time, would increase understanding of the composition and dynamics of groups for migratory species and provide a deeper understanding of the evolutionary role population-specific aggregation may be playing in navigation.

Acknowledgements. We thank W. Satterthwaite and S. Lindley for discussions and significant improvements to the manuscript, F. Ramos and D. Tollstrup for assistance with $\mathrm{Sr}$ isotopic measurements, E. Anderson and A. Clemento for assistance with genetic analyses, and P. Raimondi and C. Syms for statistical advice. Special thanks to M. Kilgour, A. Nickels, S. Reins, and A. Bachar for tissue collection and preparation. This project would not have been possible without the fishing skills of P. Parravano, J. Hie, R. Block, J. Estes, S. Berkeley, J. Figurski, S. Sogard and the crew and patrons of the 'New Captain Pete', 'The Outer Limits', and 'Dave's Albacore'. A. Smith provided GIS assistance for Fig. 1 , and G. Whitman provided editorial assistance. We thank the programs that funded this work: NOAA Fisheries through the Student Careers' Experience Program, University of California's Coastal Environmental Quality Initiative, and the Partnership for Interdisciplinary Studies of Coastal Oceans (PISCO), which is funded primarily by the Gordon and Betty Moore Foundation, the David and Lucile Packard Foundation, and the Myers Oceanographic Trust.

\section{LITERATURE CITED}

Anderson EC, Waples RS, Kalinowski ST (2008) An improved method for predicting the accuracy of genetic stock identification. Can J Fish Aquat Sci 65:1475-1486

Banks MA, Rashbrook VK, Calavetta MJ, Dean CA, Hedgecock D (2000) Analysis of microsatellite DNA resolves genetic structure and diversity of Chinook salmon (Oncorhynchus tshawytscha) in California's Central Valley. Can J Fish Aquat Sci 57:915-927

Barnett-Johnson R, Ramos FC, Grimes CB, MacFarlane RB (2005) Validation of $\mathrm{Sr}$ isotopes in otoliths by laser ablation multicollector inductively coupled plasma mass spectrometry (LA-MC-ICPMS): opening avenues in fisheries science applications. Can J Fish Aquat Sci 62: 2425-2430

Barnett-Johnson R, Grimes CB, Royer CF, Donohoe CJ (2007) Identifying the contribution of wild and hatchery Chinook salmon (Oncorhynchus tshawytscha) to the ocean fishery using otolith microstructure as natural tags. Can J Fish Aquat Sci 64:1683-1692

Barnett-Johnson R, Pearson TE, Ramos FC, Grimes CB, MacFarlane RB (2008) Tracking natal origins of salmon using isotopes, otoliths, and landscape geology. Limnol Oceanogr 53:1633-1642

Barnett-Johnson R, Teel DJ, Casillas E (2010) Genetic and otolith isotopic markers identify salmon populations in the Columbia River at broad and fine geographic scales. Environ Biol Fishes 89:533-546

Bellinger MR, Banks MA, Bates SJ, Crandall ED, Garza JC, Sylvia G, Lawson PW (2015) Geo-referenced, abundance calibrated ocean distribution of Chinook salmon (Oncorhynchus tshawytscha) stocks across the West Coast of North America. PLoS One 10:e0131276

Bentzen P, Olsen JB, McLean JE, Seamons TR, Quinn TP (2001) Kinship analysis of Pacific salmon, insights into mating, homing, and timing of reproduction. J Hered 92: 127-136

> Berdahl A, Westley PAH, Levin SA, Couzin ID, Quinn TP (2014) A collective navigation hypothesis for homeward migration in anadromous salmonids. Fish Fish doi: 10.1111/faf.12084

Bull CM, Griffin CL, Lanham EJ, Johnston GR (2000) Recognition of pheromones from group members in a gregarious lizard, Egernia stokessi. J Herpetol 34:92-99

> Campana SE, Thorrold SR (2001) Otoliths, increments, and elements: keys to a comprehensive understanding of fish populations? Can J Fish Aquat Sci 58:30-38

> Chapman MG, Underwood AJ (1999) Ecological patterns in multivariate assemblages: information and interpretation of negative values in ANOSIM tests. Mar Ecol Prog Ser 180:257-265

Clark DC, Beshear DD, Moore AJ (1995) Role of familiarity in structuring male-male social interactions in the cockroach Gromphadorhina portentosa (Dictyoptera: Blaberidae). Ann Entomol Soc Am 88:554-561

$>$ Clarke KR (1993) Non-parametric multivariate analyses of changes in community structure. Aust J Ecol 18:117-143

Clarke KR, Gorley RN (2006) PRIMER v6: user manual/tutorial. PRIMER-E, Plymouth

> Clemento AJ, Crandall ED, Garza JC, Anderson EC (2014) Evaluation of a single nucleotide polymorphism baseline for genetic stock identification of Chinook salmon (Oncorhynchus tshawytscha) in the California Current large marine ecosystem. Fish Bull 112:112-130

> Collins SM, Bickford N, McIntyre PB, Coulon A, Ulseth AJ, Taphorn DC, Flecker AS (2013) Population structure of a neotropical migratory fish: contrasting perspectives from genetics and otolith microchemistry. Trans Am Fish Soc 142:1192-1201

Czaran T (1998) Spatiotemporal models of population and community dynamics. Chapman \& Hall, London

Feyrer F, Hobbs J, Acuna S, Mahardja B and others (2015) Metapopulation structure of a semi-anadromous fish in a dynamic environment. Can J Fish Aquat Sci 72:709-721

Fraser DJ, Duchesne P, Bernatchez L (2005) Migratory charr schools exhibit population and kin associations beyond juvenile stages. Mol Ecol 14:3133-3146

French RH, Bilton H, Osako M, Hartt, A (1976) Distribution and origin of sockeye salmon (Oncorhynchus nerka) in offshore waters of the North Pacific Ocean. Int North Pac Fish Comm Bull 34:1-113

Fullerton AH, Lindley ST, Press GR, Feist BE, Steel EA, McElhany R (2011) Human influence on the spatial 
structure of threatened Pacific salmon metapopuations. Conserv Biol 25:932-944

Griffiths SW (2003) Learned recognition of conspecifics by fishes. Fish Fish 4:256-268

> Griffiths SW, Brockmark S, Höjesjö J, Johnsson JI (2004) Coping with divided attention: the advantage of familiarity. Proc R Soc B 271:695-699

> Hart PJ, Bergman E, Calles O, Erisson S and others (2014) Familiarity with a partner facilitates the movement of drift foraging juvenile grayling (Thymallus thymallus) into a new habitat area. Environ Biol Fishes 97:515-522

> Hasler AD, Wisby WJ (1951) Discrimination of stream odors by fishes and its relation to parent stream behavior. Am Nat 85:223-238

> Hay DE, McKinnell SM (2002) Tagging along: association among individual Pacific herring (Clupea pallasi) revealed by tagging. Can J Fish Aquat Sci 59:1960-1968

Helfman GA (1984) School fidelity in fishes: the yellow perch pattern. Anim Behav 32:663-672

> Hendry AP, Wenburg JK, Bentzen P, Volk EC, Quinn TP (2000) Rapid evolution of reproductive isolation in the wild: evidence from introduced salmon. Science 290: 516-518

Hilborn R (1991) Modelling the stability of fish schools: exchange of individual fish between schools of skipjack tuna (Katsuwonus pelamis). Can J Fish Aquat Sci 48: 1081-1091

Hobson KA, Barnett-Johnson RC, Cerling T (2009) Using isoscapes to track animal migration. In: West J, Bowen G, Dawson $\mathrm{T}, \mathrm{Tu} \mathrm{K}$, Tu KP (eds) Isoscapes: understanding movement patterns and processes on earth through isotope mapping. Springer Press, Berlin, p 273-297

ICES (2007) Report of the Workshop on Testing the Entrainment Hypothesis (WKTEST), 4-7 June 2007, Nantes, France. ICES CM 2007/LRC:10

Ingram BL, Weber PK (1999) Salmon origin in California as determined by otolith strontium isotope compositions. Geology 27:851-854

Johnson RC, Weber PK, Wikert JD, Workman ML, Macfarlane RB, Grove MJ, Schnitt AK (2012) Managed metapopulations: Do salmon hatchery 'sources' lead to in-river 'sinks' in conservation? PLoS ONE 7:e28880

Keefer ML, Caudill CC (2013) Homing and straying by anadromous salmonids: a review of mechanisms and rates. Rev Fish Biol Fish 24:1-36

Klimley AP, Holloway CF (1999) School fidelity and homing synchronicity in yellowfin tuna (Thunnus albacares). Mar Biol 133:307-317

Kormos B, Palmer-Zwahlen M, Low A (2012) Recovery of coded-wire tags from Chinook salmon in California's Central Valley escapement and ocean harvest in 2010. Fisheries Branch Administrative Report 2013-02. California Department of Fish and Wildlife, Sacramento, CA

Krause J, Ruxton GD (2002) Living in groups. Oxford University Press, Oxford

Lindley ST, Grimes CB, Mohr MS, Peterson W and others (2009) What caused the Sacramento River Fall Chinook stock collapse? NOAA Tech Memo, NOAA-TM-NMFSSWFSC- 447

> Lohmann KJ, Putman NF, Lohmann CMF (2008) Geomagnetic imprinting: a unifying hypothesis of long-distance and natal homing in salmon and sea turtles. Proc Natl Acad Sci USA 105:19096-19101

McKinnell S, Pella JJ, Dahlberg ML (1997) Populationspecific aggregations of steelhead trout (Oncorhynchus mykiss) in the North Pacific Ocean. Can J Fish Aquat Sci 54:2368-2376

Miller JA, Banks MA, Gomez-Uchida D, Shanks AL (2005) A comparison of population structure in black rockfish (Sebastes melanops) as determined with otolith microchemistry and microsatellite DNA. Can J Fish Aquat Sci 62:2189-2198

Milton DA, Chenery SR (2001) Can otolith chemistry detect the population structure of the shad hilsa Tenualosa ilisha? Comparison with the results of genetic and morphometric studies. Mar Ecol Prog Ser 222:239-251

> Moran P, Teel DJ, LaHood ES, Drake J, Kalinowski S (2006) Standardising multi-laboratory microsatellite data in Pacific salmon: an historical view of the future. Ecol Freshwat Fish 15:597-605

Moyle PB (1994) The decline of anadromous fishes in California. Conserv Biol 8:869-870

Myers JM, Kope RG, Bryant GJ, Teel D and others (1998) Status review of Chinook salmon from Washington, Idaho, Oregon, and California. NOAA Tech Memo, NOAATM-NMFS-NWFSC-35

> Naish KA, Carvalho GR, Pitcher TJ (1993) The genetic structure and microdistribution of shoals of Phoxinus phoxinus, the European minnow. J Fish Biol 43:75-89

Neave F (1964) Ocean migrations of Pacific salmon. J Fish Res Board Can 25:409-414

Nicholas JW, Hankin DG (1989) Chinook salmon population in Oregon's coastal river basins. Oregon Department of Fish and Wildlife, Portland, OR

> Nordeng H (1977) A pheromone hypothesis for homeward migration in anadromous salmonids. Oikos 28:155-159

Norris JG, Hyun SY, Anderson JJ (2000) Ocean distribution of Columbia River upright bright fall chinook salmon stocks. North Pac Anadromous Fish Comm Bull 2: 221-232

O'Connell M, Wright JM (1997) Microsatellite DNA in fishes. Rev Fish Biol Fish 7:331-363

O'Farrell MR, Mohr MS, Grover AM, Satterthwaite WH (2012) Sacramento River winter Chinook cohort reconstruction: analysis of ocean fishery impacts. NOAA Tech Memo, NOAA-TM-NMFS-SWFSC-49

O'Farrell MR, Mohr MS, Palmer-Zwahlen ML, Grover AM (2013) The Sacramento Index (SI). NOAA Tech Memo, NOAA-TM-NMFS-SWFSC-512

> Olsén KH (1989) Sibling recognition in juvenile arctic charr, Salvelinus alpinus (L.). J Fish Biol 34:571-581

Olsén KH, Petersson E, Ragnarsson B, Lundqvist H, Järvi T (2004) Downstream migration in Atlantic salmon (Salmo salar) smolt sibling groups. Can J Fish Aquat Sci 61: 328-331

PFMC (Pacific Fishery Management Council) (1997) Pacific Coast salmon plan. Pacific Fishery Management Council, Portland, OR

Pearcy WG (1992) Ocean ecology of North Pacific salmonids. Washington Sea Grant Program, University of Washington Press, Seattle, WA

Phillis CC, Ostrach DJ, Ingram BL, Weber PK (2011) Evaluating otolith $\mathrm{Sr} / \mathrm{Ca}$ as a tool for reconstructing estuarine habitat use. Can J Fish Aquat Sci 68:360-373

Pitcher TJ, Parrish JK (1993) Functions of shoaling behaviour in teleosts. In: Pitcher TJ (ed) Behavior of teleost fishes. Chapman \& Hall, London, p 363-439

> Porter RH, Desire L, Bon R, Orgeur P (2001) The role of familiarity in the development of social recognition by lambs. Behaviour 138:207-219 
Putman NF, Jenkins ES, Michielsens CGJ, Noakes DLG (2014) Geomagnetic imprinting predicts spatio-temporal variation in homing migration of pink and sockeye salmon. J R Soc Interface 11:20140542

Quinn TP (1984) Homing and straying in Pacific salmon. In: McCleave JD, Arnold GP, Dodson JJ, Neill WH (eds) Mechanisms of migration in fishes. Plenum Press, New York, NY, p 357-362

Quinn TP (2011) The behavior and ecology of Pacific salmon and trout. UCB Press, Vancouver

Quinn TP, Dittman AJ (1990) Pacific salmon migrations and homing mechanisms and adaptive significance. Trends Ecol Evol 5:174-177

Ramos FC, Wolff JA, Tollstrup DL (2004) Measuring ${ }^{87} \mathrm{Sr} /{ }^{86} \mathrm{Sr}$ variations in minerals and groundmass from basalts using LA-MC-ICPMS. Chem Geol 211:135-158

Ricker WE (1972) Hereditary and environmental factors affecting certain salmonid populations. In: Simon RC, Larkin PA (eds) The stock concept in Pacific salmon. University of British Columbia, Vancouver, p 19-160

Russell ST, Kelley JL, Graves JA, Magurran AE (2004) Kin structure and shoal composition dynamics in the guppy, Poecilia reticulata. Oikos 106:520-526

Ryding KE, Skalski JR (1999) Multivariate regression relationships between ocean conditions and early marine survival of coho salmon (Oncorhynchus kisutch). Can J Fish Aquat Sci 56:2374-2384

Satterthwaite WH, Mohr MS, O'Farrell MR, Wells BK (2013) A comparison of temporal patterns in the ocean spatial distribution of California's Central Valley Chinook salmon runs. Can J Fish Aquat Sci 70:574-584

Satterthwaite WH, Mohr MS, O'Farrell MR, Anderson EC and others (2014) Use of genetic stock identification data for comparison of the ocean spatial distribution, size at age, and fishery exposure of an untagged stock and its indicator: California coastal versus Klamath River Chinook salmon. Trans Am Fish Soc 143:117-133

Seeb LW, Antonovich A, Banks MA, Beacham TD and others (2007) Development of a standardized DNA database for Chinook salmon. Fisheries 32:540-552

Senar JC, Camerino M, Metcalfe NB (1990) Familiarity breeds tolerance: the development of social stability in flocking siskins (Carduelis spinus). Ethology 85:13-24

Sturrock AM, Trueman CN, Darnaude AM, Hunter E (2012) Can otolith elemental chemistry retrospectively track migrations in fully marine fishes? J Fish Biol 81: 766-795

Editorial responsibility: Ivan Nagelkerken, Adelaide, South Australia, Australia
Taylor EB (1991) A review of local adaptation in Salmonidae, with particular reference to Pacific and Atlantic salmon. Aquaculture 98:185-207

- Tucker S, Trudel M, Welch DW, Candy JR and others (2012) Annual coastal migration of juvenile Chinook salmon: static stock-specific patterns in a highly dynamic ocean. Mar Ecol Prog Ser 449:245-262

Urawa S, Nagasawa K, Margolis L, Moles A (1998) Stock identification of Chinook salmon (Oncorhynchus tshawytscha) in the North Pacific Ocean and Bering Sea by parasite tags. North Pac Anadromous Fish Comm Bull 1: 199-204

Waples RS (1991) Definition of 'species' under the Endangered Species Act: application to Pacific Salmon. NOAA Tech Memo, NOAA-TM-NMFS-NWC-194

Ward AJW, Botham MS, Hoare DJ, James R, Broom M, Godin JGJ, Krause J (2002) Association patterns and shoal fidelity in the three-spined stickleback. Proc R Soc B 269:2451-2455

> Weitkamp LA (2010) Marine distributions of Chinook salmon from the west coast of North America determined by coded wire tag recoveries. Trans Am Fish Soc 139: $147-170$

Weitkamp L, Neely K (2002) Coho salmon (Oncorhynchus kisutch) ocean migration patterns: insight from marine coded-wire tag recoveries. Can J Fish Aquat Sci 59: 1100-1115

> Wells BK, Grimes CB, Field JC, Reiss CS (2006) Covariation between the average lengths of mature coho (Oncorhynchus kisutch) and Chinook salmon (O. tshawytscha) and the ocean environment. Fish Oceanogr 15:67-79

- Wells BK, Grimes CB, Sneva JG, McPherson S, Waldvogel JB (2008) Relationships between oceanic conditions and growth of Chinook salmon (Oncorhynchus tshawytscha) from California, Washington and Alaska, USA. Fish Oceanogr 17:101-125

- Williamson KS, May B (2005) Homogenization of fall-run Chinook salmon gene pools in the Central Valley of California, USA. N Am J Fish Manag 25:993-1009

> Winans GA, Viele D, Grover A, Palmer-Zwahlen M, Teel D, Van Doornik D (2001) An update of genetic stock identification of Chinook salmon in the Pacific Northwest: test fisheries in California. Rev Fish Sci 9:213-237

Yoshiyama RM, Fisher FW, Moyle PB (1998) Historical abundance and decline of Chinook salmon in the Central Valley region of California. N Am J Fish Manag 18: $487-521$

Submitted: May 26, 2015; Accepted: January 20, 2016

Proofs received from author(s): April 11, 2016 